\title{
Geological Characteristics and Prospecting Criteria of Senji Molybdenum Ore Body in Urad Houqi, Inner Mongolia, China
}

\author{
Yonghui Su1,2, Yang Liu ${ }^{3}$ \\ ${ }^{1}$ School of Earth Sciences and Resources, China University of Geosciences (Beijing), Beijing, China \\ ${ }^{2}$ Inner Mongolia No. 1 Geological Mineral Exploration and Development Co., Ltd., Hohhot, Inner Mongolia, China \\ ${ }^{3}$ Erdaojiang Branch of Tonghua Land and Resources Bureau, Tonghua, China \\ Email:syh200@qq.com
}

How to cite this paper: Su, Y.H. and Liu Y. (2021) Geological Characteristics and Prospecting Criteria of Senji Molybdenum Ore Body in Urad Houqi, Inner Mongolia, China. International Journal of Geosciences, 12, 439-446.

https://doi.org/10.4236/ijg.2021.124024

Received: March 30, 2021

Accepted: April 27, 2021

Published: April 30, 2021

Copyright $\odot 2021$ by author(s) and Scientific Research Publishing Inc. This work is licensed under the Creative Commons Attribution International License (CC BY 4.0).

http://creativecommons.org/licenses/by/4.0/

\begin{abstract}
Geological Characteristics and Prospecting Indicators of Senji Molybdenum Ore Body in Urad Houqi, Inner Mongolia Based on geological mapping, soil geochemical survey, surface trough exploration and deep drilling verification and control, the Senji Molybdenum deposit was discovered. Geological characteristics of the molybdenum ore body are described. The host lithology of molybdenum ore body is mainly in the cataclastic carbonated black plagioclase gneiss of the second rock member of the Paleoproterozoic Baoyintu Group, followed by Early Carboniferous monzogranite. The genetic type of the deposit is preliminarily deduced to be a hydrothermal filling vein-type molybdenum deposit. The significance of this paper is to summarize the prospecting marks of the molybdenum ore body in this area, so as to further guide the exploration work in this area, and at the same time provide a useful reference for the exploration work of similar deposits in other areas.
\end{abstract}

\section{Keywords}

Orebody, Geological Features, Prospecting Criteria, Ore Deposit, Genesis, Molybdenum Ore, Urad Houqi

\section{Introduction}

The mining area is located in the Senji area of Urad Houqi, Bayan Nur City, central and western Inner Mongolia of China (Figure 1). In recent decades have found several properties in this area, as shown in Tugurige [1], chagancilao [2] gold, etc., especially in nearly a decade in Senji mining area of about $7 \mathrm{~km}$ 
southeast of found ChaGanHua large copper-molybdenum polymetallic deposit [3] [4], chagandells large molybdenum bismuth polymetallic deposit [5], etc., showing the area has good ore prospects [6] [7]. In 2011, Senji molybdenum deposit was discovered in this area. This paper describes the geological characteristics of Senji molybdenum ore body, inferred the genetic type of the deposit, and summarized the prospecting criteria of the deposit.

\section{Regional Geological Background}

Mining area is located in the north China plate (IV), the northern north China epicontinental hyperplasia $\left(\mathrm{IV}_{1}\right)$, treasure sound figure-tin event type, volcanic passive margin $\left(\mathrm{IV}_{1}{ }^{1}\right)$ [8], treasure figure uplift. The outcropings of the region include Paleoproterozoic Baoyintu Group $\left(\mathrm{Pt}_{1} B y\right)$, Upper Cretaceous Erlian Formation $\left(\mathrm{K}_{2} e\right)$, Paleogene Oligocene Huerjing Formation (E3h) and Quaternary Holocene Series (Qh). Magmatic rocks are distributed from Neoproterozoic to Early Jurassic and are dominated by acidic rocks. The mining area is characterized by complex structure, well-developed fold and fault structure, and good metallogenic geological conditions [9] [10] [11] [12].

1) Strata

The Paleoproterozoic Baoyintu Group $\left(\mathrm{Pt}_{1} B y\right)$ is located in the upper strata of the region from old to new. Mesozoic upper Cretaceous Erlian Formation $\left(\mathrm{K}_{2} e\right)$; Cenozoic Paleogene Oligocene Huler well Formation $\left(\mathrm{E}_{3} h\right)$ and Quaternary Holocene $(\mathrm{Qh})$. The Paleoproterozoic Baoyintu Group $\left(\mathrm{Pt}_{1} B y\right)$ is the most closely related to the mineralization, and its lithology is mainly quartzite, quartz schist, dimorphic quartz schist, sericite quartz schist, and carbonaceous mica quartz schist.

2) Magmatic rocks

The region is characterized by frequent magmatic activity and extensive distribution of intrusive rocks from Neoproterozoic to Early Jurassic, which are dominated by acidic rocks. It is mainly composed of Neoproterozoic gneissic granite $\left(\mathrm{Pt}_{3} \gamma\right)$, Early Carboniferous monzonite $\left(\mathrm{C}_{1} \eta \gamma\right)$, Early Permian granodiorite

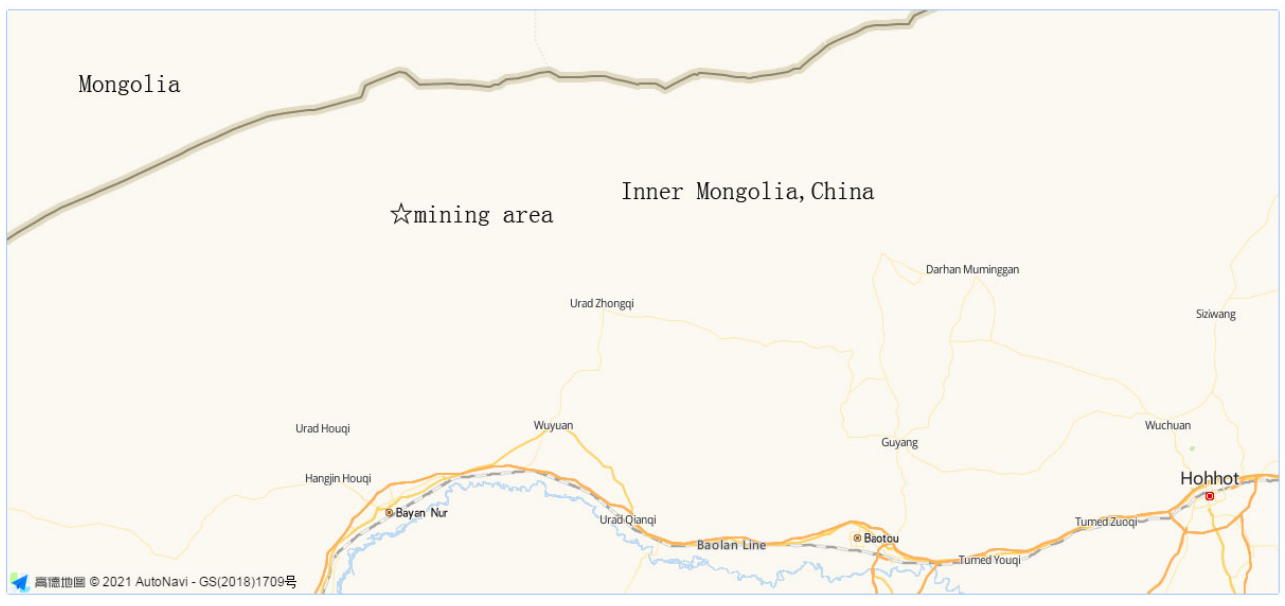

Figure 1. Traffic location map. 
$\left(\mathrm{P}_{1} \gamma \delta\right)$, and Early Jurassic biotite granite $\left(\mathrm{J}_{1} \gamma \beta\right)$. Zone of vein rocks are: quartz vein $(q)$, granite dike $(\gamma)$, granite fine-grain dike $(\gamma I)$, fine crystal dike $(I)$, crystal from granite, dike $(\gamma \rho)$, wei jing dike $(\rho)$, granite diorite Bin dike $(\gamma \delta \mu)$, flash long dike $(\delta)$, diorite Bin dike $(\delta \mu)$, quartz diorite vein $(\delta o)$, diabasic Bin dike $(\beta \mu)$, gabbro vein $(v)$, etc.

3) Metamorphism

The metamorphic rocks are widely distributed in the region, and the metamorphic degree is medium-low metamorphic. The Paleoproterozoic strata, the Neoproterozoic intrusive rocks, and the Early Carboniferous and Early Permian intrusive rocks have undergone regional metamorphism to varying degrees, and some of them have undergone mixed lithitization. Due to multiple magmatic activities and strong tectonic movements, contact metamorphic rocks and dynamic metamorphic rocks are developed to different degrees in certain sections. By comparing the development degree and scale of various metamorphic rocks, the regional metamorphism is mainly regional metamorphism, the secondary metamorphism is dynamic metamorphism, and the contact metamorphism is not developed.

4) Structure

Mining area is located in the north China plate (IV), the northern north China epicontinental hyperplasia $\left(\mathrm{IV}_{1}\right)$, treasure sound figure-tin event type, volcanic passive margin $\left(\mathrm{IV}_{1}{ }^{1}\right)$ [8]. The area has experienced many tectonic movements, complex folds, and developed faults. The overall direction of the tectonic line is NE-trending, and the NNE-trending structure is superimposed. According to the features of structural features and combinations, the development degree of various structures and the scale characteristics of these structures, they can be divided into two third-order structural units, namely, the Zhunsuhai depression and the Baoyintu uplift. The two structural units are arranged in an east-west direction. The Zuisuhai depression is a Mesozoic and Cenozoic depression, with the distribution of strata including the upper Cretaceous Erlian Formation and the Quaternary Holocene with near horizontal occurrence. The fold and fault structures in the Baoyintu uplift are well developed, and the magmatic activity is frequent. The Neoproterozoic, Early Carboniferous, Early Permian and Early Jurassic intrusive rocks are distributed in the area. The Baoyintu and Sayinhuduge fold belt has close fold structure and strong compression. The mining area is located in Baoyintu uplift area.

\section{Geological Characteristics of Orebody}

\subsection{Geological Characteristics of Orebody}

Molybdenum ore body in the mine is mainly distributed in SAP5 IV level Mo anomalies in a comprehensive anomaly. The SAP5 comprehensive anomaly is located in the east of the middle part of the survey area, with a gourd-like shape and a long axis of east-west direction, covering an area of about $2.83 \mathrm{~km}^{2}$. Anomaly is given priority to with Mo element, a category IV Mo anomalies, associated with $\mathrm{W}, \mathrm{Cu}$, the elements such as zinc, $\mathrm{Pb}$ anomalies. 
STC3, STC4, STC5, and STC6 trial trenchs were constructed in the abnormal concentration center of Mo to expose them. Molybdenum mineralization was found in the trial trenchs, with Mo grade of $0.010 \%-0.044 \%$ and the highest $0.052 \%$.

Under the control of STC3, STC4, STC5 and STC6, and nine drilling projects including SZK001, SZK002, SZK003, SZK403, SZK703, SZK803, SZK707, SZK1509 and SZK1903, only SZK707 did not find ore, and the ore rate was 93\%. According to the control of drilling engineering, the molybdenum ore bodies mainly occur in the NNW fracture structure, mainly occur in the cataclastic biotite plagioclase gneiss of the second rock member of the Paleoproterozoic Baoyintu Group, followed by the Early Carboniferous medium coarse-grained monzogranite, in the stratified, thin stratified and vein-like distribution. At present, 12 molybdenum ore bodies have been delineated, with serial numbers of Mo-1, Mo-1, ..., Mo-12, including 6 industrial molybdenum ore bodies, 6 low grade molybdenum ore bodies, ore elevation: 1375 - $725 \mathrm{~m}$. The molybdenum ore body has a strike of $155^{\circ}-200^{\circ}$, a tendency of $245^{\circ}-290^{\circ}$ and a dip of $32^{\circ}-35^{\circ}$. The molybdenum ore body is estimated to be $232-840 \mathrm{~m}$ in length and 1.35 $10.01 \mathrm{~m}$ in thickness, with a Mo grade of $0.038 \%-0.109 \%$, an average grade of $0.066 \%$ in mining area and $0.077 \%$ in industrial ore body.

The middle part of the molybdenum ore body is damaged by the NW thrust fault (F3), and the ore body is discontinuous along the dip. The buried depth of the upper wall (east) of the F3 fault is more than $300 \mathrm{~m}$, and the buried depth of the lower wall (west) is less than $300 \mathrm{~m}$.

There are three large molybdenum ore bodies in the mining area, numbered as Mo-6, Mo-8 and Mo-12 respectively. The following three molybdenum ore bodies are described as follows.

1) Mo-6 molybdenite ore body

The orebody is controlled by SZK403 and SZK803 drilling project (the control degree is low, only reaching pre-inspection). It is located on the hanging wall of F3 fault, and the western section of the orebody is damaged by F3 fault, so it belongs to blind orebody. The ore elevation is $1345-1126 \mathrm{~m}$, and it is distributed in thin layers. The orebody inclination is $245^{\circ}$, the dip Angle is $27^{\circ}$, the length is $320 \mathrm{~m}$, the true thickness is $0.89-4.46 \mathrm{~m}$, the average true thickness is $4.47 \mathrm{~m}$, and the thickness variation coefficient is $25 \%$. Ore body grade Mo: $0.032 \%-0.13 \%$, average grade Mo: $0.109 \%$, grade change coefficient $66 \%$. The ore-bearing rock is cataclastic biotite plagioclase gneiss of the second member of the Paleoproterozoic Baoyintu Group, and the surrounding rock of the roof and floor is hornblende plagioclase gneiss of the second member of the Paleoproterozoic Baoyintu Group and Early Carboniferous monzogranite.

2) Mo-8 molybdenite ore body

The ore body is controlled by SZK003 and SZK703 drilling engineering (the control degree is low, only reaching pre-inspection). It is located in the foot wall of F3 fault, and the eastern section of the ore body is damaged by F3 fault, so it is a blind ore body. Ore elevation: 1060 - $728 \mathrm{~m}$. Molybdenum ore bodies occur in 
the Early Carboniferous cataclastic monzogranite and are veined in distribution. The orebody inclination is $245^{\circ}$, the dip Angle is $32^{\circ}$. The length of the ore body is $232 \mathrm{~m}$, the true thickness is $3.99 \mathrm{~m}$, and the thickness variation coefficient is $17 \%$. The grade of ore body is $0.037 \%-0075 \%$, the average grade is $0.060 \%$, and the grade change coefficient is $21 \%$. The surrounding rock of the roof and floor is Early Carboniferous monzogranite.

3) Mo-12 molybdenite ore body

The ore body is controlled by the SZK003 drilling project (the control degree is low, only reaching the pre-inspection). It is located in the foot wall of F3 fault, and the eastern section of the ore body is damaged by F3 fault, so it belongs to the blind ore body. Ore elevation: $945-725 \mathrm{~m}$. Molybdenum ore bodies occur in cataclastic biotite plagioclase gneiss of the second rock member of Baoyintu Group in Paleoproterozoic and are distributed in vein shape. The orebody inclination is $245^{\circ}$, the dip Angle is $32^{\circ}$. The presumed length of the orebody is 323 $\mathrm{m}$, and the true thickness is $19.51 \mathrm{~m}$. The grade of ore body is $0.021 \%-0.16 \%$, the average grade is $0.075 \%$, and the grade change coefficient is $56 \%$. The ore-bearing rock is cataclastic biotite plagioclase gneiss in the second member of Baoyintu Group of Paleoproterozoic. The surrounding rock of the roof and floor is Early Carboniferous monzonite. The middle part of the orebody is divided into two orebodies by a calcite vein.

\subsection{Ore Type}

1) Natural Type

According to the degree of oxidation, the ore in the mining area is mainly primary ore, followed by oxidized ore.

According to the surface engineering, drilling engineering and water level statistics, the weathering fissure zone in the mining area is generally $10-60 \mathrm{~m}$. According to the rocks in the exploration groove, the molybdenum mineralization is weak, and the ore depth is generally $70 \mathrm{~m}$ or deeper.

The molybdenum in molybdenum ore mainly exists in the form of sulfide, which is molybdenum sulfide ore.

2) Genesis type

According to the origin of molybdenum deposits in China, they can be divided into three types: porphyry molybdenum deposits, skarn molybdenum deposits and vein molybdenum deposits. All kinds of deposits have their own properties of surrounding rock and ore body. However, each type of deposit has the same evolution process in terms of origin and material source, and all belong to the post-magmatic granite porphyry hydrothermal deposit [13] [14] [15] [16] [17]. The genetic type of Senji molybdenum deposit is preliminarily deduced to be hydrothermal filling vein type molybdenum deposit.

\subsection{Ore Body Surrounding Rock}

The ore bodies mainly occur in cataclastic carbonated biotite plagioclase gneiss 
of the second rock member of the Paleoproterozoic Baoyintu Group, followed by cataclastic Early Carboniferous monzogranite. The ore body is surrounded by hornblende plagioclase gneiss in the second rock member of Baoyintu Group of Paleoproterozoic and Early Carboniferous monzogranite.

\section{Analysis of Genesis of Ore Deposit}

There are good anomalies of $\mathrm{W}, \mathrm{Mo}, \mathrm{Cu}, \mathrm{Zn}$ and $\mathrm{Pb}$ elements in the mining area, and a certain scale industrial molybdenum ore body was found after prospecting engineering exposure. However, $\mathrm{Cu}, \mathrm{Pb}, \mathrm{Zn}$ and $\mathrm{W}$ cannot meet the requirements of industrial ore bodies. The genesis of molybdenum ore body is as follows:

1) The source of ore-forming fluids is mainly degassed magmatic water. The long-term large-scale and intense magmatic activity in the mining area is an important reason for the release of molybdenum and other ore-forming materials from the lower lithospheric mantle and the lower crustal reservoir and carrying them to the shallow part of the crust.

2) The ore-forming hydrothermal fluid rich in Mo element penetrates along the NNW fracture structure of the second order to form a molybdenum ore body. The ore-hosting lithology of the mineralized body is complex and is obviously controlled by the fault structure. The molybdenum ore body occurs in the fissure of the second-order fault structure and is controlled by the fault structure. The F3 fault is a continuous active fault. In the early stage of mineralization, various fissures formed by the fault are not only channels for ore-bearing hydrothermal migration, but also places for mineral precipitation. After the metallogenic period, the main fault of F3 continues to move, which destroys the molybdenum deposit.

3) The molybdenum ore bodies in the mining area are mainly produced in the NNW structural fracture zone of plagioclase amphibole gneiss and Early Carboniferous monzogranite in the second rock member of the Paleoproterozoic Baoyintu Group, and are produced in the form of thin layers and veins.

4) The rocks in the ore-bearing tectonic alteration zone are relatively broken, with strong dolomite, silicification and pyritization.

5) The metallogenic period is inferred to be the Early Triassic.

\section{Prospecting Marks}

The prospecting records of molybdenum ore bodies in the area are summarized as follows:

1) Distribution area of fourth-level Mo anomaly in geochemical exploration.

2) The NNW joints and fissure structure of the second-order fault structure are favorable areas for ore storage.

3) The host rocks are mainly cataclastic, carbonated, crystallized and pyritized biotite plagioclase gneiss in the second member of the Baoyintu Group of Paleoproterozoic. The mineralized altered lithology can be used as an important pros- 
pecting marker.

\section{Conflicts of Interest}

The authors declare no conflicts of interest regarding the publication of this paper.

\section{References}

[1] Li, Y., Xiong, Y.Q., Shao, G.Y., et al. (2019) A Study of Fluid Inclusions from Tugurige Gold Deposit, Inner Mongolia: Constraint on Ore Genesis. Mineral Deposits, 38, 319-330.

[2] Guo, J., Luan, H.Z., Zhou, X.T., et al. (2017) Geological Characteristics and Origin of Chagancilao Gold Deposit in Urad Zhongqi, Inner Mongolia. Shandong Land and Resources, 33, 31-36.

[3] Liu, Y.F., Nie, F.J., Jiang, S.H., et al. (2012) Ore-Forming Granite form Chaganhua Molybdenum Deposit, Central Inner Mongolia, China: Geochemistry, Geochronology and Petrogenesis. Acta Petrologica Sinica, 28, 409-420.

[4] Liu, Y.F., Nie, F.J., Jiang, S.H., et al. (2011) Ore-Forming Fluid. Characteristics and Ore Genesis of Chaganhua Porphyry Molybdenum Deposit, Inner Mongolia, China. Journal of Jilin University (Earth Science Edition), 41, 1794-1805.

[5] Zhang, Y.F. and Liang, S. (2017) Geochemistry of Ore-Forming Fluids and Genesis of Chagandells Molybdenum Deposit in Inner Mongolia. Northwestern Geology, 50, 106-114.

[6] Liu, J.D., Liang, S., Xiao, R.G., et al. (2015) Geochemistry, Geochronology and Petrogenesis of the Ore-Forming Intrusive Body in the Baoyintu Molybdenum Deposit, Inner Mongolia. Geology in China, 42, 149-168.

[7] Yang, F., Xiao, R.G., Li, N., et al. (2013) REE Geochemical Characteristics and Genesis of Granites in Baoyintu Molybdenum Deposit, Inner Mongolia. Geoscience, 27, 831-840.

[8] Shao, J.D., Wang, H., Zhang, M., et al. (2011) Inner Mongolia Tectonic Units Divided and Geological Features. Resources, 12, 51-56.

[9] Inner Mongolia Geology and Mineral Exploration and Development Bureau (1991) Inner Mongolia Regional Geology. Geological Publishing House, Beijing, 589-609.

[10] Peng, R.M., Zhai, Y.S., Han, X.F., et al. (2007) Mineralization Response to the Structural Evolution in the Langshan Orogenic Belt, Inner Mongolia. Acta Petrologica Sinica, 23, 679-687.

[11] Shen, C.L., Chen, Z.Y. and Chang, Z.Y. (2004) The Caledonian Foldbelt or the North China Platform Does the Buyant Uplift in Inner Mongolia Belong to? Geological Survey and Research, 27, 18-22.

[12] Inner Mongolia Geology and Mineral Exploration and Development Bureau (1996) Inner Mongolia Rock Formations. China University of Geosciences Press, Wuhan, 263-264.

[13] Zhou, J.C. and Zhou, K. (2017) Enetic Types and Geological Characteristics of Molybdenum Deposits in China. China Molybdenum Industry, 41, 18-22.

[14] Qu, Y.Y. (2013) Comparison on Geochemical Characteristics of Ore-Forming Magamatic Rocks in Baoyintu Porphyry Molybdenum Mine and Chilean Porphyry Copper-Molybdenum Belt. China University of Geosciences, Beijing.

[15] Shen, C.L., Zhang, M., Yu, X.Q., Chen, W.G., et al. (2010) New Progresses in Ex- 
ploration of Molybdenum Deposits and Analysis of Mineralization Prospect in Inner Mongolia. Geology and Exploration, 46, 0561-0575.

[16] Li, G.Y., Li, Z.D., Wang, J.Y., et al. (2020) Zircon U-Pb and Molybdenite Re-Os Ages and Geological Significance of the Chaganhua Molybdenum Deposit, Urad Rear Banner, Inner Mongolia. Geoscience, 34, 494-503.

[17] Li, S.M., Li, J.C., Li, T., et al. (2020) Characteristics and Genetic Indication Significance of Fluid Inclusions in the Zhujiawa Molybdenum Deposit. Geology in China, 47, 426-439. 